\title{
Control of binucleate cell migration in the placenta of sheep and goats
}

\author{
F. B. P. Wooding, A. P. F. Flint, R. B. Heap, G. Morgan, H. L. Buttle* \\ and I. R. Young † \\ AFRC Institute of Animal Physiology, Babraham, Cambridge CB2 4AT, U.K.; * National Institute \\ for Research in Dairying, Shinfield, Reading RG2 9AT, U.K.; and †Department of Physiology, \\ Monash University, Clayton, Victoria 3148, Australia
}

Summary. In the ruminant placenta $15-20 \%$ of the trophectodermal epithelium consists of granulated binucleate cells (BNC). In the sheep the granules contain ovine placental lactogen (oPL). These cells migrate from the trophectoderm to form fetomaternal hybrid tissue from implantation to term.

The number of BNC, their percentage migration and the potential secretory activity of the syncytium they form were estimated by semiquantitative transmission electronmicroscopical techniques after several surgical techniques and hormone or drug infusions.

BNC numbers decrease normally just before parturition, and this fall could be eliminated by fetal hypophysectomy or induced early by administration of tetracosactrin to intact or hypophysectomized fetuses. If only one twin was treated with tetracosactrin the placenta of the untreated twin did not show the fall in BNC numbers found in the other unless it died in utero some time before sampling. This indicates fetal control of BNC number and migration.

However, fetal catheterization, hypophysectomy, stalk section, adrenalectomy, infusion of mouse epidermal growth factor or bromocriptine had little or no effect on binucleate cell numbers or migration percentages. Maternal carunclectomy, ovariectomy, or epostane or bromocriptine administration also had no consistent significant effect.

Previous reports of degeneration of BNC structure plus a decrease in their number (with bromocriptine) or an increase in migration frequency (after adrenalectomy or stalk section) have not been confirmed by this study. The BNC migration delivers the oPL-containing BNC granules close to the maternal circulation but the variation in migration seems only loosely correlated with the reported maternal oPL concentrations.

The results indicate that $\mathrm{BNC}$ migration is independent of the hormonal milieu, but that BNC production is greatly modified by the hormonal changes just before parturition, with cortisol production by the fetus a possible primary cause.

\section{Introduction}

Binucleate cells with characteristic granules are found in all ruminant placentae which have been examined histologically so far (Amoroso, 1952; Wooding, 1982). They occur in high frequency in the fetal trophectoderm throughout gestation, consistently forming between 15 and $20 \%$ of the cells in that layer but abruptly decreasing shortly before parturition (Wooding, 1983). They first appear just after blastocyst elongation and seem to play a crucial role in ruminant implantation (Wathes \& Wooding, 1980; Wooding \& Staples, 1981; Wooding, 1984). 
Binucleate cell development and fine structure are very similar in all ruminants so far studied. There is also evidence which suggests that all share the capacity to migrate out of the trophectoderm to fuse with maternal uterine epithelial cells or derivatives (Wooding, 1982) and thereby deliver their characteristic granules close to the maternal connective tissue for subsequent release by exocytosis. In the sheep these granules have been shown by immunoelectron-microscopical techniques to contain ovine placental lactogen (Wooding, 1981).

The control of the production and migration of binucleate cells may thus play a vital role in ruminant implantation and placental growth. It has been suggested that fetal pituitary stalk section (Steven et al., 1978), fetal adrenalectomy (Barnes, Comline, Silver \& Steven, 1976) or bromocriptine administration (Lowe et al., 1979a) affect the growth and/or mobility of these cells. This paper reports the first quantitative study of binucleate cell distribution after various treatments to the pregnant ewe or fetus, the object being to identify the factors controlling this cell population.

\section{Materials and Methods}

Animals. Animals were drawn from herds at Babraham, Physiology Department, Cambridge University, Monash University, Australia, and the National Institute for Research in Dairying, Shinfield. Dated pregnancies were achieved by using a male with a sire ram harness and monitoring the ewes daily for dye marking, and taking goats in oestrus to the billy. The breeds of animals used are identified in the tables.

Tissue preparation. The methods which have been used to prepare the placental tissue for electron microscopy, to count the binucleate cells and to produce a migration percentage have been detailed elsewhere (Wooding, 1983). Briefly, the animals were killed with an overdose of pentobarbitone sodium (or a placentome was removed during surgery), the placentome(s) were perfused with a glutaraldehyde fixative with or without subsequent osmium, and processed via alcohol and propyleneoxide to araldite. Sections were stained with phosphotungstic acid (non-osmicated tissue) or with uranyl acetate and lead citrate (osmicated tissue) and the counting was done on the electron microscope. For estimation of the proportion of cell types in the trophectodermal epithelium only cells containing a nuclear profile were counted. When a binucleate cell had two nuclear profiles only one was added to the total. All nuclei along one strip of trophectodermal epithelium were counted until the number in the uninucleate category reached 100 . This constitutes one 'observation' (see tables). The count was then repeated at random non-overlapping positions on sections including the entire depth of the placentomal villi. Binucleate cells which formed part of the apical trophectodermal tight junction were classified as migrating. This produces a migration percentage which does not represent a rate of migration unless it is assumed that the speed of the movement of the binucleate cell through the tight junction is the same at all stages of pregnancy. The autoradiographic evidence (Wooding, Flint, Heap \& Hobbs, 1981) supports this for two periods (midand late) during normal ovine pregnancy but it cannot be assumed to hold throughout normal pregnancies or in those that have been experimentally modified. The frequency of granules in the syncytium was scored as,+++ or +++ , and the classification was reproducible with different assessors. This estimation assumes that the syncytial area was fairly constant.

Surgical procedures. Fetal hypophysectomy was carried out by electrocautery and the success of ablation was monitored by the amount of $\mathrm{LH}$ released after a GnRH challenge and by histology (Ricketts \& Flint, 1980b). Carunclectomy performed during anoestrus removed on average $60 \%$ of the caruncles in the year before that in which pregnancy was established (Ricketts \& Flint, 1980a). Ovariectomy and catheterization of the fetal tarsal or jugular vein or maternal jugular vein for infusions and/or sampling were carried out as described elsewhere (catheters for EGF infusion: Thorburn, Waters, Young, Dolling \& Buntine, 1981; ovariectomy: Staples, Heap, Wooding \& 
King, 1983). Methods for pituitary stalk section (Steven et al., 1978), adrenalectomy (Barnes et al., 1976) or infusion of bromocriptine (Lowe et al., 1979a, b) to the fetus have been reported previously.

Conventionally fixed (immersion or perfusion) and embedded samples of placentomes were made available by D. H. Steven from the experiments reported by Barnes et al. (1976), Lowe et al. (1979a, b) and Steven et al. (1978), and were used for counting. Pituitary stalk section was performed via the frontal bone with a silicone rubber block injected to maintain division of the stalk (Nathanielsz et al., 1978).

Epostane (WIN 32729: $(2 \alpha, 4 \alpha, 5 \alpha, 17 \beta) 4,5$-epoxy-17 hydroxy-4,17 dimethyl, 3-oxo-andiostane2-carbonitrile) is a steroid synthesis inhibitor (Taylor, Jenkin, Robinson \& Thorburn, 1982a) and was a generous gift from Dr W. E. Jones, Sterling Winthrop Ltd, Surbiton, Surrey. This was administered intramuscularly to the dam, unless otherwise specified, as were progesterone (Intervet, Cambridge) and bromocriptine (Sigma, London). Tetracosactrin (Synacthen) was from Ciba, Horsham U.K.

\section{Results}

The variation of placentomal binucleate cell populations throughout normal pregnancy is shown in Table 1: the figures (from Wooding, 1983) provide a standard for comparison with the results from treated sheep detailed below. No significant differences were observed between primiparous and multiparous animals. Mean values for binucleate cells were within the normal $5 \%$ error range at different levels of the same placentome or in different placentomes from a singleton fetus. However, in twin pregnancies the binucleate cell percentages could be markedly different between the placentomes of each placenta if only one fetus was catheterized and infused (e.g. Table 2, Nos 5 and 10), although normally the levels would be similar (Wooding, 1983). Granules were present in the syncytium that were equivalent morphologically to those in the binucleate cell, and there is good evidence (Wooding, 1982) that these are derived solely from binucleate cell migration and fusion into the syncytium. Their numbers vary considerably and an attempt has been made to estimate their relative numbers on a three level scale,,+++ or +++ (Tables $1-5)$.

Table 1. Frequency and migration of fetal binucleate (BNC) cells in the trophectoderm of untreated sheep and goats (adapted from Wooding 1983)

\begin{tabular}{|c|c|c|c|c|}
\hline $\begin{array}{l}\text { No. of animals } \\
\text { used (no. of } \\
\text { observations*) }\end{array}$ & $\begin{array}{l}\text { Stage of } \\
\text { gestation } \\
\text { (days p.c.) }\end{array}$ & $\begin{array}{l}\% \mathrm{BNC} \text { in } \\
\text { the trophectoderm } \dagger\end{array}$ & $\begin{array}{l}\% \text { of BNC } \\
\text { migratingt }\end{array}$ & $\begin{array}{l}\text { Frequency of } \\
\text { 'BNC-type' } \\
\text { granules in } \\
\text { the syncytium }\end{array}$ \\
\hline \multicolumn{5}{|l|}{ Sheep (Soay and Clun) } \\
\hline $5(38)$ & $70-105$ & $18 \pm 1$ & $26 \pm 2$ & +++ \\
\hline $5(42)$ & $114-140$ & $17 \pm 2$ & $18 \pm 1$ & +++ \\
\hline $5(54)$ & $142-147$ & $8 \pm 3$ & $20 \pm 4$ & + \\
\hline \multicolumn{5}{|c|}{ Goats (Toggenburg, Saanen, Saanen $\times$ Welsh) } \\
\hline $4(24)$ & $27-90$ & $21 \pm 2$ & $21 \pm 2$ & $+t+$ \\
\hline $4(40)$ & $100-134$ & $21 \pm 1$ & $23 \pm 2$ & +++ \\
\hline
\end{tabular}

\footnotetext{
*One 'observation' is the number of BNC per 100 uninucleate trophectoderm cells and the percentage of those BNC that were migrating.

†Values are mean \pm s.e.m.
} 


\section{Fetal hypophysectomy (Group A, Table 2)}

Three singleton hypophysectomized fetuses were given no further treatment. Pregnancy was prolonged to well past the expected time of delivery but binucleate cell numbers $(13-16 \%)$ and migration frequencies (13-20\%) were not significantly different from those found in placentomes sampled at the time of the operation. Such figures represent the lower end of the normal range

Table 2. Frequency and migration of fetal binucleate cells (BNC) in the trophectoderm of sheep after modification of the fetal pituitary or adrenal

\begin{tabular}{|c|c|c|c|c|c|}
\hline Group $\ddagger$ & $\begin{array}{c}\text { Ewes (no. of } \\
\text { observations } † \text { ) }\end{array}$ & $\begin{array}{l}\text { Treatment (days p.c.) } \\
\rightarrow \text { sampling age } \\
\quad(\text { days } p . c .)\end{array}$ & $\begin{array}{l}\% \text { of BNC in } \\
\text { phectoderm } \S\end{array}$ & $\begin{array}{l}\% \text { of } \mathrm{BNC} \\
\text { migrating } \$\end{array}$ & $\begin{array}{l}\text { Frequency of } \\
\text { 'BNC-type' } \\
\text { granules in } \\
\text { the syncytium }\end{array}$ \\
\hline A & $\begin{array}{l}\text { Fetal hypophys } \\
1 \\
2 \\
3\end{array}$ & $\begin{array}{l}\text { ctomy }(\mathrm{HX}) \text {, post-term Caesarean delivery }(\mathrm{CD}) \\
\text { HX: } \rightarrow 119-129 \\
\text { CD: } \rightarrow 164-166\end{array}$ & $\begin{array}{l}13 \pm 1 \\
15 \pm 1\end{array}$ & $\begin{array}{l}17 \pm 3 \\
17 \pm 3\end{array}$ & $\begin{array}{l}+++ \\
+++\end{array}$ \\
\hline B & $\begin{array}{l}\text { Fetal hypophysec } \\
4 \quad(6) \\
5 \mathrm{a}(14) \\
5 \mathrm{~b}(12) \\
6 \mathrm{a}(13) \\
6 \mathrm{~b}(17) \\
7 \quad(13) \\
8 \quad(11)\end{array}$ & $\begin{array}{lrl}\text { ctomy (HX) } & \text { catheterization }(\mathrm{C}) \text { and tetracosactri } \\
\text { HXC: } 123 \text {; ACTH: } & 127 \rightarrow 131 \\
\text { HXC: } 122 \text {; ACTH: } & 128 \rightarrow 132 \\
\text { Non-HX: } & 122 ; \text { none } \rightarrow 132 \text { (twin) } \\
\text { HXC: } 123 \text {; ACTH: } & 12912 \text { h only } \rightarrow 133 \\
\text { Non-HXC: } 123 \text {; ACTH: } & 130 \rightarrow 133 \text { (twin) } \\
\text { HXC: } 124 \text {; ACTH: } & 136 \rightarrow 140 \\
\text { HXC: } 119 \text {; ACTH: } & 137 \rightarrow 140\end{array}$ & $\begin{array}{l}\text { in infusion }(A \\
* * 8 \pm 1 \\
* * 10 \pm 1 \\
18 \pm 1 \\
13 \pm 1 \\
* * 5 \pm 1 \\
22 \pm 1 \\
* * 4 \pm 1\end{array}$ & $\begin{array}{l}\text { CTH), } 5 \mu \mathrm{g} / \mathrm{h} \\
18 \pm 5 \\
* * 12 \pm 2 \\
19 \pm 2 \\
23 \pm 3 \\
* 9 \pm 3 \\
23 \pm 4 \\
* 8 \pm 3\end{array}$ & $\begin{array}{l}+++ \\
+++ \\
+++ \\
+ \\
+ \\
+++ \\
+++\end{array}$ \\
\hline C & $\begin{array}{l}\text { Fetal catheter }(\mathrm{C}) \\
9(15) \\
10 \mathrm{a}(12) \\
10 \mathrm{~b}(12) \\
11 \quad(12) \\
12 \mathrm{a}(6) \\
12 \mathrm{~b}(8) \\
13(10) \\
14 \mathrm{a}(13) \\
14 \mathrm{~b}(5) \\
15 \quad(4) \\
16 \quad(5)\end{array}$ & 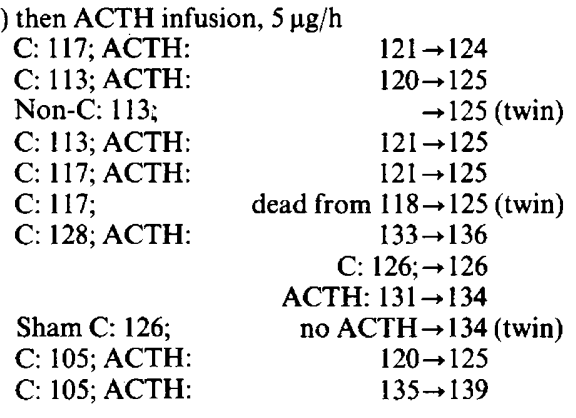 & $\begin{array}{r}17 \pm 1 \\
* * 1 \pm 1 \\
14 \pm 1 \\
* 6 \pm 1 \\
* * 2 \pm 1 \\
* * 1 \pm 1 \\
* * 8 \pm 1 \\
14 \pm 1 \\
* * 4 \pm 1 \\
14 \pm 1 \\
* * 6 \pm 1 \\
* * 5 \pm 1\end{array}$ & $\begin{array}{r}22 \pm 3 \\
8 \pm 6 \\
18 \pm 2 \\
* 30 \pm 6 \\
6 \pm 5 \\
0 \\
19 \pm 3 \\
18 \pm 3 \\
21 \pm 9 \\
9 \pm 2 \\
20 \pm 8 \\
17 \pm 5\end{array}$ & $\begin{array}{c}+++ \\
++ \\
++ \\
++ \\
++ \\
+ \\
++ \\
+++ \\
+ \\
+ \\
\text { ND } \\
\text { ND }\end{array}$ \\
\hline D & $\begin{array}{l}\text { Fetal stalk secti } \\
17 \quad(12) \\
18 \mathrm{a}(10) \\
18 \mathrm{~b}(12) \\
19 \quad(4)\end{array}$ & $\begin{array}{l}\text { n (SS) catheterization }(\mathrm{C}) \text { and infusion } \\
\text { SSC: } 109 \text {; saline infusion } 110 \rightarrow 124(\mathrm{CD}) \\
\text { SSC: } 108 \text {; saline infusion } 109 \rightarrow 124 \\
\text { SSC: } 108 \text {; ACTH infusion } \\
\text { (twin, } 1 \mu \mathrm{g} / \mathrm{h}) 117 \rightarrow 124 \\
\text { SSC: } 108 \text {; cortisol infusion } \\
11 \mathrm{mg} / 24 \mathrm{~h}\end{array}$ & $\begin{array}{r}21 \pm 1 \\
17 \pm 1 \\
* * 9 \pm 1 \\
{ }^{*} 9 \pm 2\end{array}$ & $\begin{array}{r}26 \pm 3 \\
* 24 \pm 2 \\
12 \pm 4 \\
33 \pm 8\end{array}$ & $\begin{array}{l}\text { ND } \\
\text { ND }\end{array}$ \\
\hline $\mathbf{E}$ & \begin{tabular}{ll}
\multicolumn{2}{l}{ Fetal adrenalecto } \\
$20 \mathrm{a}$ & $(5)$ \\
$20 \mathrm{~b}$ & $(4)$ \\
21 & $(7)$ \\
22 & $(5)$
\end{tabular} & $\begin{aligned} & \text { ADX: } 128 ; \rightarrow 143(\mathrm{CD}) \\
& \text { Non-ADX: } 128 \rightarrow 143(\mathrm{CD}) \\
& \text { ADX: } 128 \rightarrow 147 \text { (CD) } \\
& \text { ADX: } 128 \rightarrow 143 \text { (CD) }\end{aligned}$ & $\begin{array}{r}6 \pm 1 \\
6 \pm 1 \\
11 \pm 1 \\
10 \pm 1\end{array}$ & $\begin{array}{r}* * 1 \pm 1 \\
7 \pm 7 \\
11 \pm 3 \\
10 \pm 3\end{array}$ & $\begin{array}{l}\text { ND } \\
\text { ND } \\
\text { ND } \\
\text { ND }\end{array}$ \\
\hline
\end{tabular}

Significance levels (when compared with the results in Table 1): ${ }^{*} P<0 \cdot 01 ;{ }^{* *} P<0.001$.

ND, not determined.

tOne observation is the number of BNC per 100 uninucleate trophectoderm cells and the percentage of those BNC that were migrating.

$\S$ Values are mean \pm s.e.m.

†Groups A, B and C, Clun Forest sheep; Groups D and E, Welsh Mountain sheep. 
Table 3. Frequency and migration of fetal binucleate cells (BNC) in trophectoderm after epidermal growth factor or bromocriptine administration to sheep or goats

\begin{tabular}{|c|c|c|c|c|c|}
\hline \multicolumn{2}{|c|}{$\begin{array}{c}\text { Animal No. } \\
\text { (no. of } \\
\text { Group* observations } \dagger \text { ) }\end{array}$} & $\begin{array}{l}\text { Treatment (days p.c.) } \\
\rightarrow \text { sampling age } \\
\text { (days p.c.) }\end{array}$ & $\begin{array}{c}\% \text { of } \mathrm{BNC} \\
\text { in trophectoderm }\end{array}$ & $\begin{array}{l}\% \text { of BNC } \\
\text { migrating }\end{array}$ & $\begin{array}{l}\text { Frequency of } \\
\text { 'BNC-type' } \\
\text { granules in } \\
\text { the syncytium }\end{array}$ \\
\hline \multirow[t]{3}{*}{$\mathbf{F}$} & \multicolumn{5}{|c|}{ Epidermal growth factor (EGF) or saline (S) infusion to fetus $(0.5 \mathrm{mg} / 24 \mathrm{~h})$} \\
\hline & $23-27(39)$ & C: $111 ;$ EGF: $115 \rightarrow 120$ & $18 \pm 1$ & $18 \pm 2$ & $+t+$ \\
\hline & $28-30(29)$ & C: $110 ; S: 114 \rightarrow 119$ & $19 \pm 1$ & $20 \pm 2$ & $++t$ \\
\hline \multirow[t]{9}{*}{$\mathrm{G}$} & \multirow{2}{*}{\multicolumn{5}{|c|}{ Bromocriptine administration }} \\
\hline & \multirow{2}{*}{$31(8)$} & C: 115 ; fetal infusion & & & \\
\hline & & i.v. $0.7 \mathrm{mg} / \mathrm{h} 128 \rightarrow 138$ & $17 \pm 1$ & $24 \pm 3$ & $++t$ \\
\hline & \multirow[t]{2}{*}{$32-34(15)$} & $\begin{array}{l}\text { Maternal injections i.m. } \\
1 \mathrm{mg} / 24 \mathrm{~h} \text { for } 5 \text { days }\end{array}$ & & & \\
\hline & & before sampling $\rightarrow 73-93$ & $20 \pm 1$ & $20 \pm 4$ & +++ \\
\hline & \multirow[t]{2}{*}{$35-37(18)$} & Saline injections (controls) & & & \\
\hline & & as above $\rightarrow 75-105$ & $19 \pm 1$ & $22 \pm 3$ & +++ \\
\hline & \multirow[t]{2}{*}{$38(6)$} & $\begin{array}{l}\text { Maternal injection i.m. } \\
2 \mathrm{mg} / 24 \mathrm{~h} \text { for } 5 \text { days }\end{array}$ & & & \\
\hline & & before sampling $\rightarrow 136$ & $17 \pm 1$ & $16 \pm 3$ & +++ \\
\hline \multirow[t]{7}{*}{$\mathrm{H}$} & \multicolumn{5}{|c|}{ Bromocriptine administration } \\
\hline & \multirow{6}{*}{$\begin{array}{l}39 \\
40 \\
41 \\
42(15) \\
43(15)\end{array}$} & $\begin{array}{l}\text { Maternal injections i.m. } \\
5 \mathrm{mg} / 12 \mathrm{~h} \text { for } 3 \text { days }\end{array}$ & & & \\
\hline & & before sampling $\rightarrow 100,130$ & $20 \pm 1$ & $22 \pm 2$ & + \\
\hline & & Saline injections (controls) & & & \\
\hline & & $\rightarrow 90,130$ & $20 \pm 1$ & $20 \pm 1$ & +++ \\
\hline & & Maternal injections i.m. & & & \\
\hline & & $10 \mathrm{mg} / 24 \mathrm{~h}$ for 4 days $\rightarrow 134$ & $18 \pm 1$ & $23 \pm 1$ & + \\
\hline
\end{tabular}

Values are mean \pm s.e.m.

$C$, catheterization.

${ }^{*}$ Group F, Corriedale sheep; Group G, Clun Forest sheep; Group H, Saanen goats.

TOne observation is the number of BNC per 100 uninucleate trophectoderm cells and the percentage of those BNC that were migrating.

for this stage of pregnancy. There were frequent binucleate cell-type granules in the syncytium in all specimens examined. No fetus produced any LH when injected with GnRH (for details, see Ricketts \& Flint, 1980b) just before delivery by Caesarean section, confirming the absence of active pituitary tissue as indicated from histological results. The 3 fetuses all showed evidence of postmaturity. There were no behavioural or other indications of the onset of labour in the ewes before delivery by Caesarean section.

Fetal hypophysectomy or catheterization with or without infusion of tetracosactrin (Groups B and C, Table 2)

The ewes carrying hypophysectomized or intact fetuses, when infused with tetracosactrin, delivered naturally or by Caesarean section 3-5 days later. The placentomes of 12 out of 14 infused animals had significantly lower $(P=0.01$ or 0.001$)$ binucleate cell percentages $(1-10 \%)$ than would be 'normal' for that stage of pregnancy $(17 \%$, Table 1$)$. When only one twin was infused with tetracosactrin (Nos 5a, 6a, 10a, 14a) the other (Nos 5b, 6b, 10b, 24b) had a 'normal' number of binucleate cells whether or not it had previously been hypophysectomized. Of the 2 exceptions to the pattern of decreasing binucleate cell number after tetracosactrin infusion, one (No. 9) (nonhypophysectomized) showed normal $(17 \%)$, the other (No. 7) a rather higher $(P=0.05)$ than normal $(22 \%)$, numbers of binucleate cells. In one animal in which both intact twins (Nos 12a, 12b) 
Table 4. Frequency and migration of binucleate cells (BNC) in trophectoderm after carunclectomy or laparotomy

\begin{tabular}{|c|c|c|c|c|c|}
\hline Grou & $\begin{array}{c}\text { Animal No. } \\
\text { (no. of } \\
\ddagger \text { observations) } †\end{array}$ & $\begin{array}{c}\text { Treatment (days p.c.) } \\
\rightarrow \text { sampling age } \\
\quad \text { (days p.c.) }\end{array}$ & $\begin{array}{l}\% \text { of BNC in } \\
\text { trophectoderm }\end{array}$ & $\begin{array}{l}\% \text { of BNC } \\
\text { migrating }\end{array}$ & $\begin{array}{l}\text { Frequency of } \\
\text { 'BNC-type' } \\
\text { granules in } \\
\text { the syncytium }\end{array}$ \\
\hline $\mathrm{J}$ & Carunclectomy ( & CX) & & & \\
\hline & $44(6)$ & CX: Year 1; Year $2 \rightarrow 70$ & $20 \pm 2$ & $30 \pm 3$ & ND \\
\hline & $45(5)$ & CX: Year 1; Year $2 \rightarrow 70$ & $* 22 \pm 1$ & $* 20 \pm 1$ & ND \\
\hline & $46(5)$ & Sham CX: Year 1; Year $2 \rightarrow 70$ & $* 22 \pm 1$ & $* 19 \pm 2$ & ND \\
\hline & $47(5)$ & Sham CX: Year 1; Year $2 \rightarrow 70$ & $* * 27 \pm 2$ & $* * 17 \pm 1$ & ND \\
\hline K & Laparotomy $(\mathbf{L})$ & & & & \\
\hline & $48(6)$ & L: 118 ; fetal injection & & & \\
\hline & & i.m. $\rightarrow 118$ & $15 \pm 1$ & $21 \pm 2$ & +++ \\
\hline & & $\mathrm{CD} \rightarrow 132$ & $17 \pm 1$ & $21 \pm 3$ & +++ \\
\hline & $49(7)$ & L: 104; fetal injection & & & \\
\hline & & i.m. $\rightarrow 104$ & $21 \pm 1$ & $21 \pm 3$ & \\
\hline & & $\mathrm{CD} \rightarrow 105$ & $19 \pm 1$ & $22 \pm 2$ & +++ \\
\hline & $50(10)$ & L: 65 ; fetal injection & & & \\
\hline & & i.m. $\rightarrow 65$ & $21 \pm 1$ & $26 \pm 3$ & $++t$ \\
\hline & (8) & $\mathrm{CD} \rightarrow 72$ & $22 \pm 1$ & $24 \pm 1$ & $+t+$ \\
\hline
\end{tabular}

Values are mean \pm s.e.m.

Significance levels (when compared with the results in Table 1): ${ }^{*} P<0 \cdot 01,{ }^{* *} P<0 \cdot 001$.

$\mathrm{ND}$, not determined. CD, Caesarean delivery.

FOne observation is the number of BNC per 100 uninucleate trophectoderm cells and the percentage of those BNC that were migrating.

†Group J, Clun Forest sheep; Group K, Clun Forest sheep, except for No. 50 (Saanen $\times$ Welsh goat).

were catheterized, one died 3 days before a tetracosactrin infusion was given to the survivor; both fetuses were delivered normally 4 days later and significant decreases $(P=0.001)$ in the binucleate cell numbers (down to $1 \%$ and $2 \%$ ) were found in both sets of placentomes. The dead fetus (No. 12b) showed a very well preserved trophectoderm firmly interdigitated with the syncytium (Figs 1 , $2 \& 3$ ), although the cells in the cores of the fetal villi were degenerating. The percentages of binucleate cells crossing the microvillar junction showed no consistent changes with administration of tetracosactrin; in the 12 animals in which binucleate cell numbers had significantly decreased 7 were unchanged, 4 significantly higher. In the 2 animals (Nos 7 and 11) in which tetracosactrin did not affect binucleate cell numbers, the numbers crossing were also unchanged. Non-infused twins had one normal (No. 10b) and one low (No. 14b) crossing figure for binucleate cells.

The amounts of binucleate cell type granules in the syncytium showed no correlation with the figures for total or migrating binucleate cells.

\section{Fetal pituitary stalk section (Group D, Table 2)}

Counts were made on placentomal material from 4 stalk sectioned fetuses. The two without further treatment (Nos 17 and 18a) showed no significant departure from 'normal' binucleate cell numbers (Table 1), when the animals were killed 14 days after surgery. However, the degree of migration of binucleate cells was significantly higher than normal in one case. Fetus $18 \mathrm{~b}$ (the twin of No. 18a) was infused with tetracosactrin resulting in premature delivery of both fetuses on Day 124 p.c. No. 19, a singleton, was induced with cortisol and was born on Day 117 p.c. Both animals had binucleate cell numbers characteristic of full-term placentas, significantly lower than the results for Days 114-139 p.c. In neither animal was the binucleate cell migration percentage significantly different from normal. 
Adrenalectomy (Group E, Table 2)

In 3 adrenalectomized fetuses and a non-adrenalectomized twin of one of the three, the binucleate cell numbers were all within the normal range (Table 1) immediately pre partum. The figures for the binucleate cell migration were lower than normal in all 4 fetuses but only one (No. 20a) showed a significant decrease.

\section{Epidermal growth factor ( $E G F$ ) (Group F, Table 3)}

Administration of EGF to fetuses has been reported to produce changes such as premature lung maturation and hair follicle development and an increased concentration of ovine placental lactogen in maternal blood (Thorburn et al., 1981).

No effect of EGF infusion was detected on binucleate cell structure, numbers, or migration percentage when compared with saline-infused controls or the 'normal' range (Table 1). The frequency of binucleate cell-type granules in the syncytium was also unchanged.

Table 5. Frequency and migration of binucleate cells (BNC) in trophectoderm after epostane administration or ovariectomy

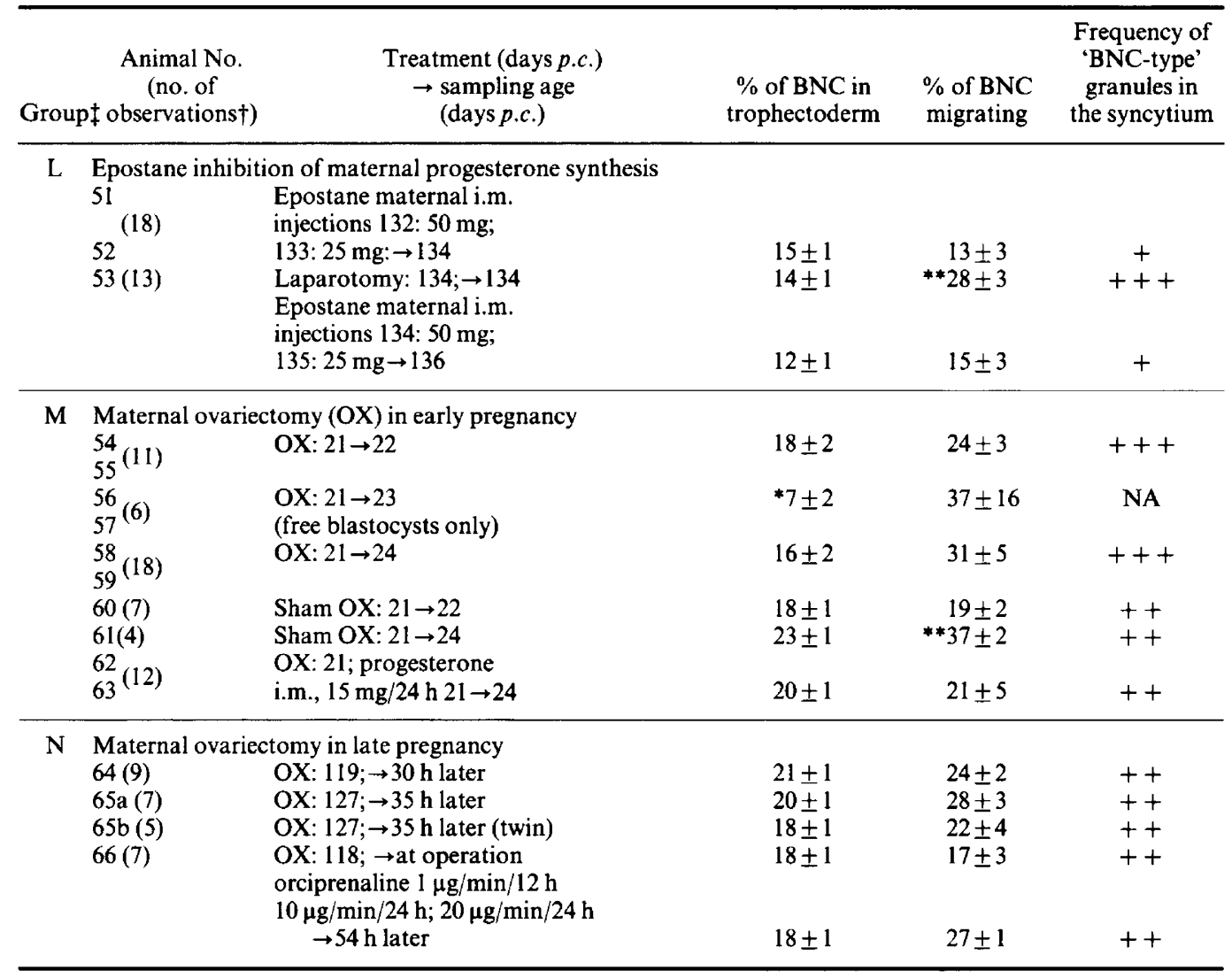

Values are mean \pm s.e.m.

Significance levels (when compared with Table 1): ${ }^{*} P<0.01,{ }^{* *} P<0.001$; NA, not applicable.

fOne observation is the number of BNC per 100 uninucleate trophectoderm cells and the percentage of those BNC that were migrating.

†Groups L and M, Clun Forest sheep; Group N, Saanen goats. 


\section{Bromocriptine infusion (Groups $G$ and $H$, Table 3)}

Bromocriptine, a dopamine agonist, which blocks prolactin secretion by the pituitary, had no significant effect on binucleate cell numbers when administered either to the mother (goats, sheep) or the fetus (sheep) and only one animal (No. 29) out of the 8 animals treated had a significantly different (higher, 27 \pm 2 ) binucleate cell migration percentage. The morphology of the binucleate cells appeared normal; no evidence of significant numbers of degranulated, pycnotic or otherwise structurally abnormal binucleate cells was observed during the counting. The frequency of binucleate cell-type granules in the syncytium appeared to be unaffected.

\section{Carunclectomy (Group J, Table 4)}

In 2 ewes the number of caruncles and therefore subsequent placentomes was drastically reduced surgically before pregnancy to an average of 14 compared with the normal 90 . The residual placentomes were considerably larger than normal and constituted more than $80 \%$ of the total weight of the more numerous control placentomes. No significant differences were found between binucleate cell numbers of the sham-operated controls and the carunclectomized animals. There was a significant increase in binucleate cell migration in the carunclectomized animals. However, when compared with the normal range at 70 days p.c., only one, No. 44 , fell within the normal range. The other 3 had significantly higher binucleate cell numbers and lower migration percentages.

\section{Laparotomy (Group K, Table 4)}

No significant changes were observed in binucleate cell numbers or migration (in 2 sheep, and 1 goat) 1 day (No. 49), 1 week (No. 50) or 2 weeks (No. 48) after laparotomy under halothane anaesthesia for injection of radioactive thymidine into the fetus through the intact uterine wall.

\section{Epostane inhibition of progesterone synthesis (Group L, Table 5)}

Injection of Epostane (WIN 32729) which blocks conversion of pregnenolone to progesterone, produced premature delivery after $30-36 \mathrm{~h}$ in the 3 sheep treated. No significant differences were found in binucleate cell numbers when one sample taken immediately before injection and samples from the 3 treated animals at delivery were compared. The 1 animal (No. 53) that was sampled before injection showed a significant difference (higher, $P=0.001$ ) in the binucleate cell migration percentage when compared with the 'normal' range.

The frequency of binucleate cell-type granules in the syncytium varied considerably.

\section{Ovariectomy (Groups $M$ and $N$, Table 5)}

In early pregnancy sheep are dependent upon the corpus luteum for progesterone production, and ovariectomy results in abortion within 4-5 days.

Figs 1-3. Micrographs showing the excellent structural preservation of the fetal trophectoderm (asterisks) in the placentomes of a fetus (No. 12b) which died in utero 7 days before the tissue was perfused via the uterine artery. BNC are rare $(1 \%$ compared with the normal $17 \%$, Table 1) but normal in structure and range of development where they appear (arrows: Fig. 2 shows a young BNC; Fig. 1 part of a mature granulated BNC). The normality of the ultrastructure in the uninucleate trophectoderm cells is illustrated in Fig. 3, whereas some of the cells in the core of the fetal villi are degenerating (Fig. 2, arrowhead). pc, Perfused maternal capillary.

Fig 1, $\times 1900 ;$ Fig. 2, ×6000; Fig. 3, × 40000 . 


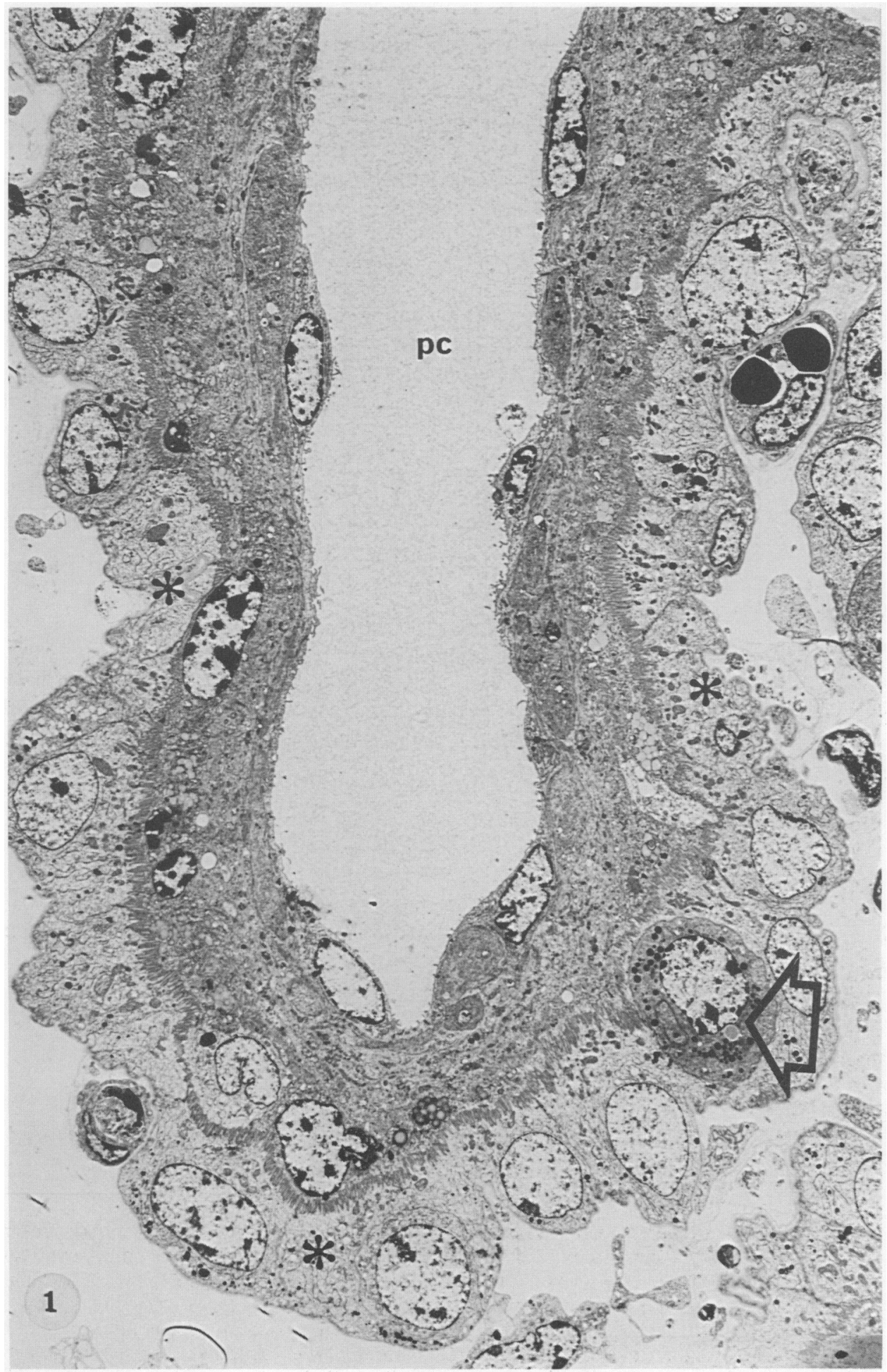




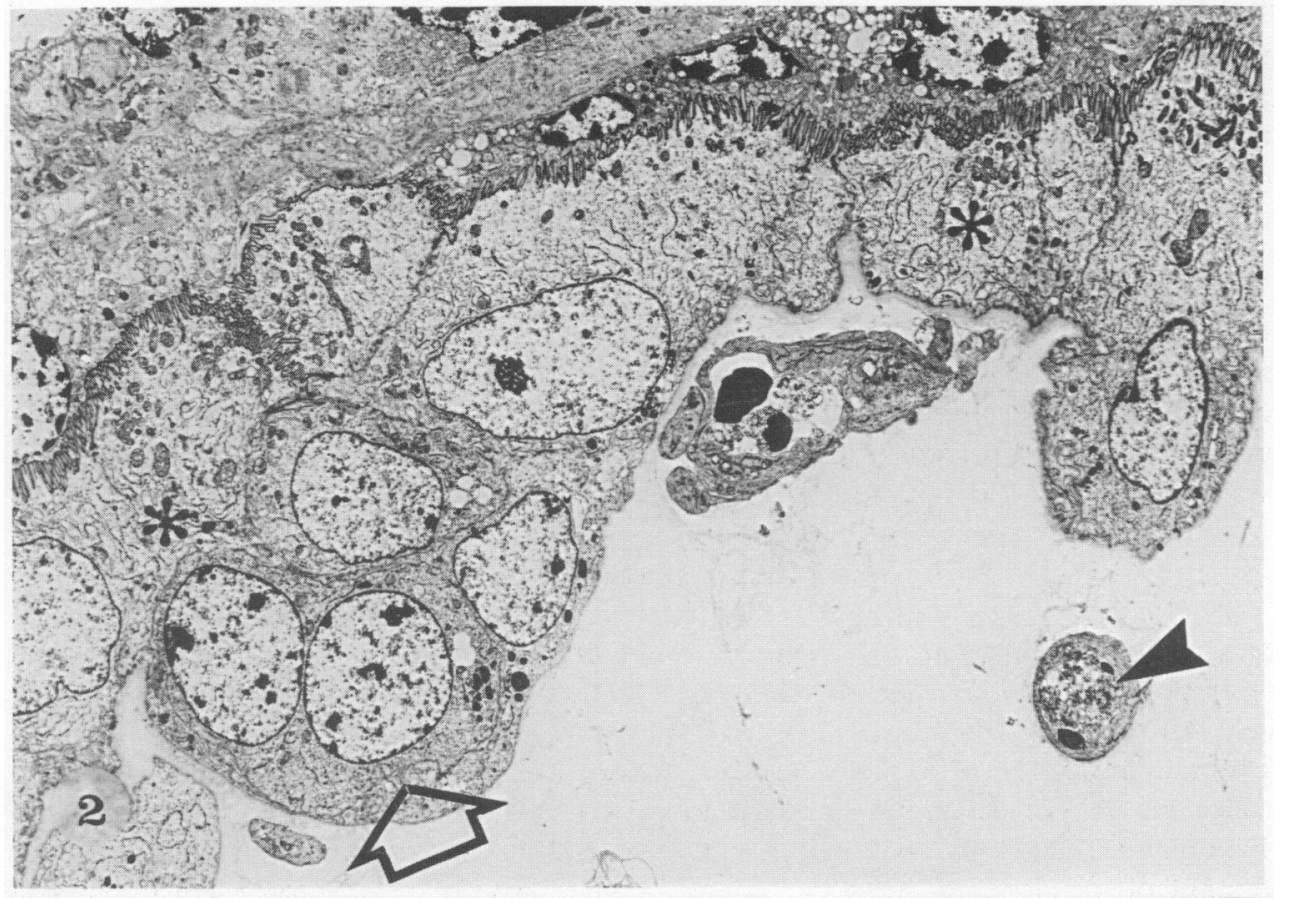

I.

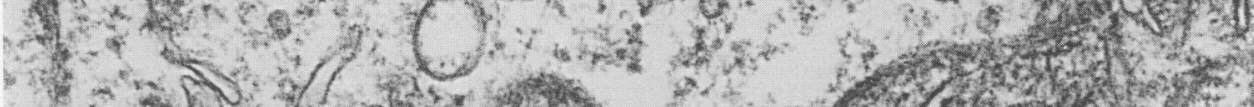

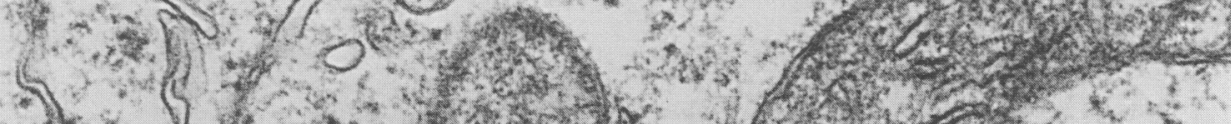

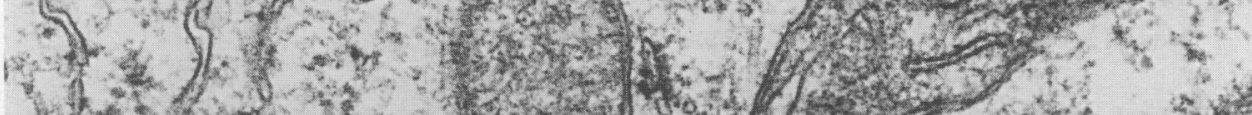

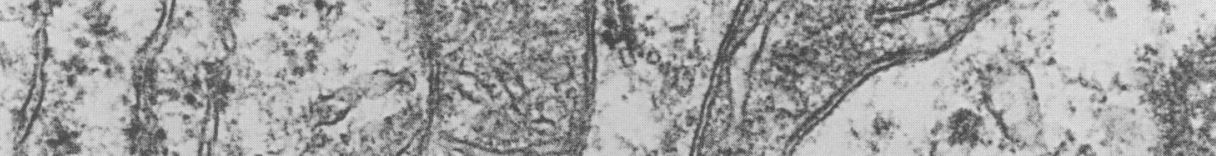
IP. 16 in a

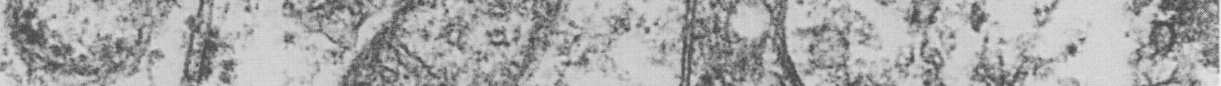

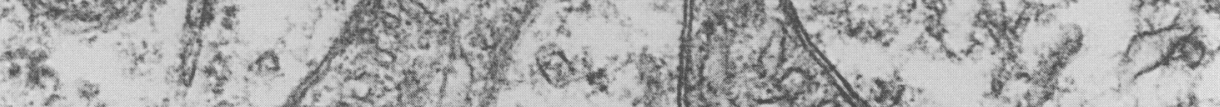

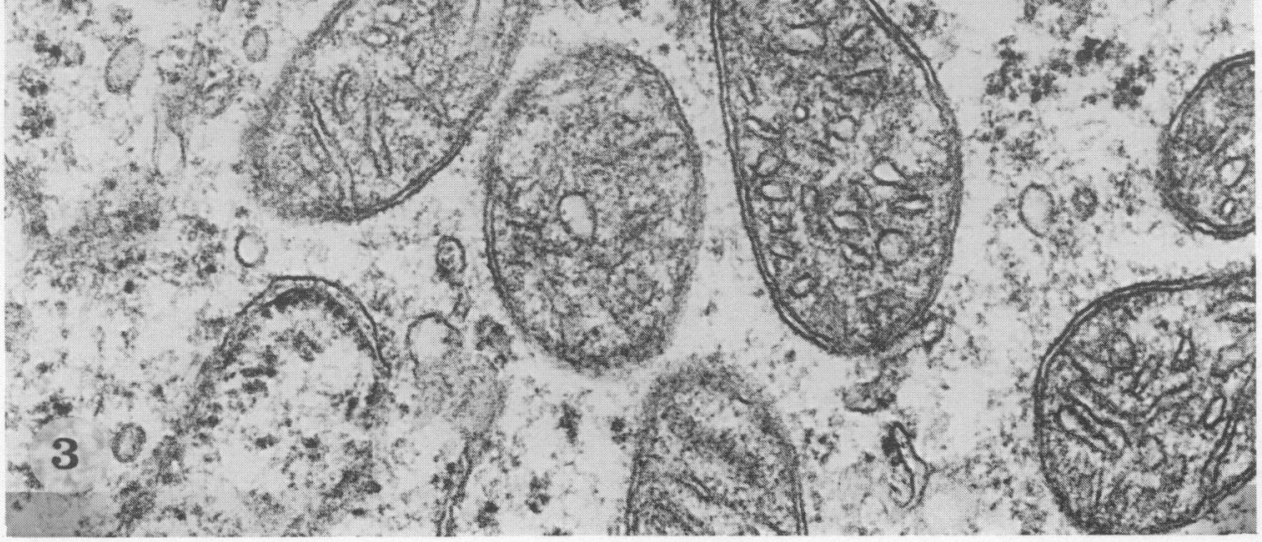


Sheep ovariectomized at 21 days p.c. and killed 1, 2 or 3 days later had numbers and migration of binucleate cells equivalent to those of sham-operated or ovariectomized ewes given subsequent progesterone injections. There was only one figure statistically different from normal (No. 61, migration percentage) and it must be remembered that there is a wide variation in local binucleate cell numbers at this early stage. This is illustrated by the low total binucleate cell figures for random areas of the free blastocyst (Nos 56 and 57). The bulk of the results represents counts over the caruncles where the blastocyst is closely apposed and the binucleate cell population consistently high.

Goats are dependent upon progesterone from the ovary throughout pregnancy but ovariectomy late in pregnancy (119-127 days p.c.) had no detectable effect on binucleate cell numbers or migration even when the abortion consequent on ovariectomy was delayed for $36 \mathrm{~h}$ by orciprenaline infusion (No. 66). Granules were found at similar frequency in all animals examined.

\section{Discussion}

The present results represent the first detailed and quantitative assessment of binucleate cell populations and their migrations after various surgical and pharmacological treatments. Binucleate cell numbers were decreased in 12 out of 14 animals, before their normal pre-partum fall (Wooding, 1983) by administration of tetracosactrin or cortisol to the fetus. This treatment also induces parturition within 3 or 4 days. The pre-partum fall and subsequent parturition were prevented by fetal hypophysectomy ( 3 out of 3 ) and restored by tetracosactrin infusion to a hypophysectomized fetus ( 3 out of 4 ). None of the other treatments (see below) had any consistent effect on the binucleate cell numbers, and no manipulation reproducibly changed the binucleate cell migration percentage.

The reduction in $\mathrm{BNC}$ numbers after tetracosactrin infusion was local since the saline or non-infused twin of the treated fetus did not show any corresponding decrease. The rate of binucleate cell production would therefore seem to be reduced by the hormonal or other chanes at parturition. However, there were exceptions and none of the evidence suggests that a decrease in binucleate numbers is obligatory in the initiation of parturition. In contrast to the fetal experiments, treatments to the ewes which produced abortion (ovariectomy at 21 days p.c.) or premature delivery (inhibition of progesterone synthesis with epostane at 134 days p.c.) did not affect the binucleate cell structure, numbers or migration.

The production of binucleate cells therefore seems to be a fetal function rather than a response to a maternal stimulus. This suggestion is supported by the decrease in binucleate cell production in only the tetracosactrin-perfused fetus of twins and the similar decrease in the placenta of a twin that died 7 days before sampling. The placental trophectoderm of the dead fetus (No. 12b) was normal on all ultrastructural criteria (Figs 1-3) but binucleate cells were very rare.

Fetal pituitary stalk section (Steven et al., 1978) or adrenalectomy (Barnes et al., 1976) have been reported to increase the migration percentage. Counts made on material from the Steven et al. (1978) and Barnes et al. (1976) experiments indicated a significant increase in migration percentage of only 1 of the 2 stalk-sectioned fetuses and a decrease with adrenalectomy. The difference between the results may be due to the fact that the considerable normal migration level was not realized by these authors and that migrations do occasionally occur in groups (Wooding, 1983). Systematic counting of an acceptably large statistical sample on sections where the migrations are highlighted (Wooding, 1980, 1983) provides a much more reliable method of establishing the basic data than random observations.

Bromocriptine administration to fetus or ewe (Lowe et al., 1979a) has been reported to increase the binucleate cell migration percentages and cause degranulation and degeneration of the binucleate cells. We could neither reproduce nor confirm these results. We evaluated placental material from our own experimental animals (intramuscular injection) and from one of the 
reportedly most severely affected animals from the study of Lowe et al. (1979a: No. 6R532, fetal infusion; in the present study No. 31). We could find no significant differences from our controls or from the normal range for the particular stage of pregnancy.

There have been three independent reports that only the binucleate cells and specifically their granules contain the protein hormone ovine placental lactogen ( $\mathrm{PL}$ ), also known as ovine chorionic somatommamotrophin (oCS) (Martal, Djiane \& Dubois, 1977; Watkins \& Reddy 1980; Wooding, 1981). There is one report of a more general chorionic distribution, excluding the binucleate cells (Carnegie, Chan, McCully, Robertson \& Friesen, 1982), but the light micrographs are lacking in resolution, difficult to interpret and unconvincing. Ovine placental lactogen is present during pregnancy only, in maternal and fetal circulations. It first appears in the conceptus just before implantation, rises to a peak value in the maternal circulation at 120-130 days p.c. and declines to a low figure at term (Martal \& Djiane, 1977; Taylor et al., 1978; Chan, Robertson \& Friesen, 1978). A similar pattern has been reported for caprine placental lactogen (Hayden, Thomas, Smith \& Forsyth, 1980. This pattern correlates well with the numbers of binucleate cells present in the placenta. After fetal hypophysectomy the normal fall in the maternal placental lactogen concentration towards term does not occur, fetal death in utero causes a rapid decrease, and bromocriptine administration is without effect (Taylor et al., 1982a; Taylor, McQuillen, Jenkin, Robinson \& Thorburn, 1982b; Taylor, Robinson, Jenkin \& Thorburn, 1983a, b). These effects are also consistent with binucleate cell migration and exocytosis being the sole source of ovine placental lactogen in the maternal circulation.

However, there are major drawbacks to this hypothesis. For example, in this study fetal infusion of tetracosactrin consistently caused a decrease in the number of binucleate cells in the placentomes of intact or hypophysectomized fetuses, whereas Taylor et al. (1983a) found an unchanged level, or even an increase in the ovine placental lactogen concentration in maternal and fetal circulations after a similar treatment with tetracosactrin.

Furthermore, Thorburn et al. (1981) reported that maternal ovine placental lactogen concentrations increased by up to $300 \%$ after an infusion of epidermal growth factor (EGF) to the fetus. Counts on cotyledonary material from animals infused at the same EGF level showed no change in the binucleate cell numbers or migration percentage. Although bromocriptine as used by Taylor $e t$ al. (1983b) and Martal \& Djiane (1978) in ewes had no effect on maternal or fetal serum concentrations, Lowe et al. (1979b) in sheep and Buttle, Cowie, Jones \& Turvey (1979) in goats have claimed a decrease in ovine placental lactogen or total lactogenic activity in maternal serum after use of the drug. There appears to be a fundamental statistical error in the treatment of results by Lowe et al. (1979b); using the same methods of calculation detailed in that paper we can find no significant differences between the stated (p. 775) ovine placental lactogen levels in bromocriptinetreated $(470 \cdot 1 \pm 97.2 \mathrm{ng} / \mathrm{ml}$, mean \pm s.e., $\mathrm{N}=5)$ and control $(395 \cdot 2 \pm 68.9 \mathrm{n} / \mathrm{ml}, \mathrm{N}=5)$ ewes. The further claim of a within-animal significant difference, with no figures given, must therefore be equally suspect. In the Buttle et al. (1979) experiment the goats were hemimastectomized and kept warm $\left(18-22^{\circ} \mathrm{C}\right)$ which produced a prolactin concentration much higher than would be usual at this stage of pregnancy. With the much simpler experimental design used in the present paper (no hemimastectomy, normal temperatures, twice the bromocriptine dose but given i.m. for 4 days only) no changes were detected in total lactogenic activity or prolactin (which was within the normal (low) range for this stage of pregnancy) or in binucleate cell numbers or migration percentages. The decrease in total lactogenic activity found in the Buttle et al. (1979) study may therefore be a reflection of the unusual conditions or some unique property of the batch of bromocriptine used, rather than an expression of a primary action of bromocriptine on the binucleate cell population and its derivatives. This is corroborated by the study of Forsyth, Byatt \& Iley (1985) using longterm bromocriptine treatment to goats; no changes in total lactogenic activity were detected. On balance the evidence seems against any consistent direct effect of bromocriptine on placental lactogen concentrations or binucleate cell behaviour.

However, Martal \& Lacroix (1978) found an increase in the ovine placental lactogen content of 
the placenta, even though the serum concentrations were unchanged, and this is a reminder that there are several possible control points. Assuming that all the ovine placental lactogen originates from the binucleate cell granules, changes in the rates of binucleate cell production, maturation or migration, or of granule exocytosis could affect the placental lactogen concentration in maternal serum. An augmented level of placental lactogen in the placenta but not the blood would result from an increase in any of the rates above except the last. However, no consistent increase in the number of granules in the syncytium was observed in this study after bromocriptine treatment between Days 70 and 95 p.c. (Nos. 32-34), nor was there any consistent decrease in syncytial granules when the binucleate cell numbers drop after ACTH administration (Nos 4-14). Here again the anatomical results do not correlate with the reported changes in placental lactogen.

Exocytosis from the syncytium would have an immediate effect only on the maternal placental lactogen level. It affords no explanation for the origin of the placental lactogen in the fetal circulation. There is no close correlation between maternal and fetal blood concentrations of placental lactogen during pregnancy (Chan et al., 1978; Taylor et al., 1978) and although they follow a similar pattern there are sufficient differences of detail to indicate that they are controlled independently. ${ }^{125} \mathrm{I}$-labelled ovine placental lactogen injected into the maternal circulation does not cross into the fetal blood or vice versa (Grandis \& Handwerger, 1983).

The hypothesis that the binucleate cells synthesize and store all the goat and sheep placental lactogen and that they all migrate to form the syncytium from which the granules are released to the maternal circulation fits well with much of the published work. However, we still know little about how binucleate cell production and migration are regulated and previous reports of changes induced by fetal stalk section, adrenalectomy or bromocriptine administration have not been confirmed in this study. The basic facts concerning the distribution and behaviour of the binucleate cell population have now been clearly outlined. The results indicate that the fetus is directly involved in maintaining binucleate cell production, and that the hormonal changes before parturition block this process. Once produced it seems that the binucleate cell will mature and migrate whatever the conditions.

\section{References}

Amoroso, E.C. (1952) Placentation. In Marshall's Physiology of Reproduction, 3rd edn, ch. 15, pp. 127-311. Ed. A. S. Parkes, Longmans Green, London.

Barnes, R.J., Comline, R.S., Silver, M. \& Steven, D.H. (1976) Ultrastructural changes in the placenta of the ewe after foetal hypophysectomy or adrenalectomy. J. Physiol., Lond. 263, 173-174.

Buttle, H., Cowie, A.T., Jones, E.A. \& Turvey, A. (1979) Mammary growth during pregnancy in hypophysectomized or bromocriptine treated goats. J. Endocr. 80, 343 -351.

Carnegie, J.A., Chan, J.S.D., McCully, M.E., Robertson, H.A. \& Friesen, H.G. (1982) The cellular localization of chorionic somatomammotrophin in ovine chorion. J. Reprod. Fert. 66, 9-16.

Chan, J.S-D., Robertson, H.A. \& Friesen, H.G. (1978) Maternal and fetal concentrations of ovine placental lactogen measured by radioimmunoassay. J. Endocr. 102, 1606-1613.

Forsyth, I.A., Byatt, J.C. \& Iley, S. (1985) Hormone concentrations, mammary development and milk yield in goats given long term bromocriptine treatment in pregnancy. J. Endocr. 104, 77-85.

Grandis, A.S. \& Handwerger, S. (1983) Differential effects of ornithine on placental lactogen and growth hormone secretion in the pregnant ewe and foetus. $J$. Endocr. 97, 175-178.

Hayden, T.J., Thomas, C.R., Smith, S.S. \& Forsyth, I.A. (1980) Placental lactogen in the goat in relation to stage of gestation, number of foetuses, metabolites, progesterone and time of day. J. Endocr. 86, 279-290.

Lowe, K.C., Beck, N.F.G., McNaughton, D.C., Jansen, C.A.M., Thomas, A.L., Nathanielsz, P.W., Mallon, K. \& Steven, D.H. (1979a) Ultrastructural changes in the placenta of the ewe after long term intravascular infusion of 2-Bromo- $\alpha$-ergocryptine (CB154) into mother or fetus. Q. Jl exp. Physiol. 64, 253-262.

Lowe, K.C., Beck, N.F.G., McNaughton, D.C., Gluckman, P.D., Kaplan, S.L., Grumbach, M.M. \& Nathanielsz, P.W. (1979b) Effect of long term bromocriptine infusion on plasma prolactin and ovine chorionic somatomammotropin in the pregnant ewe and fetal sheep. Am. J. Obstet. Gynecol. 135, $773-777$.

Martal, J. \& Djiane, J. (1977) The production of chorionic somatomammotrophin in the sheep. $J$. Reprod. Fert. 49, 285-289.

Martal, J. \& Lacroix, M.C. (1978) Production of chorionic somatomammotropin (OCS), fetal growth and growth of the placenta and corpus luteum in 
ewes treated with 2-Bromo- $\alpha$-ergocryptine. Endocrinology 103, 193-199.

Martal, J., Djiane, J. \& Dubois, M.P. (1977) Immunofluorescent localization of ovine placental lactogen. Cell Tissue Res. 184, 427-433.

Nathanielsz, P.W., Abel, M.H., Bass, F.G., Krane, E.J., Thomas, A.L. \& Liggins, G.C. (1978) Pituitary stalk section and some of its effects on endocrine function in the fetal lamb. Q. Jl exp. Physiol. 63, 211-219.

Ricketts, A.P. \& Flint, A.P.F. (1980a) Onset of the synthesis of progesterone by the ovine placenta. $J$. Endocr. 86, 337-347.

Ricketts, A.P. \& Flint, A.P.F. (1980b) Induction of labour in sheep: an investigation of the possible involvement of a fetal pituitary secretion in the activation of placental enzymes by cortisol. Placenta 1, 287-297.

Staples, L.D., Heap, R.B., Wooding, F.B.P. \& King, G.J. (1983) Migration of leucocytes into the uterus after acute removal of ovarian progesterone during early pregnancy in the sheep. Placenta 4, 339-350.

Steven, D.H., Bass, F., Jansen, C.J.M., Krane, E.J., Mallon, K., Samuel, C.A., Thomas, A.L. \& Nathanielsz, P.W. (1978) Ultrastructural changes in the placenta of the ewe after fetal pituitary stalk section. Q. Jl exp. Physiol. 63, 221-229.

Taylor, M.J., Jenkin, G., Chan, J.S.D., Friesen, H.G., Thorburn, G.D. \& Robinson, J.S. (1978) Ovine placental lactogen in maternal and fetal plasma in sheep. J. Endocr. 79, 39-40P, Abstr.

Taylor, M.J., Jenkin, G., Robinson, J.S. \& Thorburn, G.D. (1982a) Regulation of ovine placenal lactogen: lack of correlation with progesterone secretion. $J$. Endocr. 95, 275-279.

Taylor, M.J., McQuillen, K., Jenkin, G., Robinson, J.S. \& Thorburn, G.D. (1982b) The regulation of OPL: the role of the fetal hypothalamic-pituitary axis. $J$. dev. Physiol. 5, 251-258.

Taylor, M.J., Robinson, J.S., Jenkin, G. \& Thorburn, G.D. (1983a) Ovine placental lactogen concentrations during premature delivery induced by infusion of dexamethasone or ACTH to the fetus. J. Endocr. 98, 197-200.
Taylor, M.J., Jenkin, G., Robinson, J.S. \& Thorburn, G.D. (1983b) Effect of intrauterine death and fetectomy on OPL production. Res. vet. Sci. 35, 22-24.

Thorburn, G.D., Waters, K.J., Young, I.R., Dolling, M. \& Buntine, D. (1981) Epidermal Growth Factor: a critical factor in fetal maturation. In The Fetus and Independent Life (Ciba Fdn Symp. No. 86), pp. 172-198. Eds K. Elliott \& S. Parkes. Pitman, London.

Wathes, D.C. \& Wooding, F.B.P. (1980) An electron microscopic study of implantation in the cow. Am.J. Anat. 159, 285-306.

Watkins, W.B. \& Reddy, S. (1980) Ovine placental lactogen in the cotyledonary and intercotyledonary placenta of the ewe. J. Reprod. Fert. 58, 411-414.

Wooding, F.B.P. (1980) Electronmicroscopic localization of binucleate cells in the sheep placenta using phosphotungstic acid. Biol. Reprod. 22, 357-365.

Wooding, F.B.P. (1981) Localization of ovine placental lactogen in sheep placentomes by electron microscope immunocytochemistry. J. Reprod. Fert. 62, $15-19$.

Wooding, F.B.P. (1982) The role of the binucleate cell in ruminant placental structure. J. Reprod. Fert., Suppl. 31, 31-39.

Wooding, F.B.P. (1983) Frequency and localization of binucleate cells in the placentomes of ruminants. Placenta 4, 527-540.

Wooding, F.B.P. (1984) Role of binucleate cells in fetomaternal cell fusion at implantation in the sheep. Am. J. Anat. 170, 233-250.

Wooding, F.B.P. \& Staples, L.D. (1981) Functions of the trophoblast papillae and binucleate cells in implantation in the sheep. J. Anat. 133, 110-112.

Wooding, F.B.P., Flint, A.P.F., Heap, R.B. \& Hobbs, T. (1981) Autoradiographic evidence for migration and fusion of cells in the sheep placenta; resolution of a problem in placental classification. Cell. Biol. Int. Rep. 5, 821-827. 